\title{
Serum High-Sensitivity Cardiac Troponin T Is a Significant Biomarker of Left-Ventricular Diastolic Dysfunction in Subjects with Non-Diabetic Chronic Kidney Disease
}

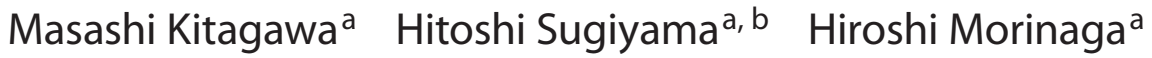 \\ Tatsuyuki Inoue $^{a}$ Keiichi Takiue $^{a}$ Yoko Kikumoto $^{a}$

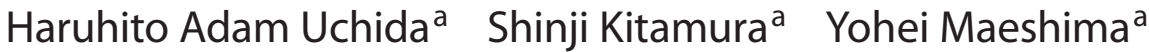 \\ Norihisa Toh ${ }^{c}$ Kazufumi Nakamura ${ }^{c}$ Hiroshi Ito $^{c}$ \\ Hirofumi Makino ${ }^{a}$ \\ ${ }^{a}$ Department of Medicine and Clinical Science, ${ }^{b}$ Center for Chronic Kidney Disease and \\ Peritoneal Dialysis, and ' ${ }^{C}$ Department of Cardiovascular Medicine, Okayama University \\ Graduate School of Medicine, Dentistry and Pharmaceutical Sciences, Okayama, Japan
}

\section{Key Words}

Albuminuria $\cdot$ Annular velocity $\cdot$ Chronic kidney disease $\cdot$ High-sensitivity cardiac troponin T . Left-ventricular diastolic dysfunction - Peak early diastolic mitral annular velocity · Tissue Doppler imaging $\cdot$ Troponin T

\begin{abstract}
Background: Chronic kidney disease (CKD) is associated with left-ventricular (LV) diastolic dysfunction (LVDD) which progresses to diastolic heart failure. However, biomarkers predicting LVDD in patients with CKD are largely unknown. Methods: In 93 patients with non-diabetic CKD, the relationships among echocardiography, high-sensitivity cardiac troponin $\mathrm{T}$ (hs-cTnT), B-type natriuretic peptide (BNP), and renal function were evaluated. LV mass index, peak early diastolic mitral filling velocity (E), peak early diastolic mitral annular velocity $\left(E^{\prime}\right)$, and $E / E^{\prime}$ were recorded. Results: The $\mathrm{E}^{\prime}$ values were significantly decreased and E/E', BNP, and hs-cTnT increased with increasing CKD stage. The CKD patients with LVDD with $\mathrm{E}^{\prime}<5 \mathrm{~cm} / \mathrm{s}$ had a significantly higher hs-cTnT level as well as a significantly higher BNP level compared to those with $\mathrm{E}^{\prime}$ $\geq 5 \mathrm{~cm} / \mathrm{s}$. The area under the receiver-operating characteristic curve for hs-cTnT and BNP to de-


tect $E^{\prime}<5 \mathrm{~cm} / \mathrm{s}$ was $0.880(p=0.0101)$ and $0.741(p=0.0570)$, respectively. In multivariate analysis, hs-cTnT and albuminuria were significantly associated with $\mathrm{E}^{\prime}$, and estimated glomerular filtration rate with the hs-cTnT level, after adjusting for age, cause of CKD, and other parameters. Conclusions: These data suggest that hs-cTnT may be a useful biomarker of LVDD in nondiabetic CKD patients.

Copyright $\odot 2011$ S. Karger AG, Basel

\section{Introduction}

The prevalence of heart failure with preserved ejection fraction (EF) has increased over time, while the rate of death from this disorder has remained unchanged [1]. Individuals with heart failure with a normal EF are typically older and more likely to be female, and also have a higher likelihood of hypertension, obesity, renal failure, anemia, and atrial fibrillation [1]. In addition, chronic kidney disease (CKD) is associated with an increased mortality in patients with heart failure, and CKD-associated mortality is higher in patients with diastolic than systolic heart failure [2]. The European Working Group on heart failure with a normal EF proposed a new diagnostic algorithm in 2007 [3]. The early diastolic velocity of the longitudinal motion of the mitral annulus $\left(\mathrm{E}^{\prime}\right)$ reflects the rate of myocardial relaxation. The velocity of the mitral annulus can be recorded by tissue Doppler imaging (TDI), and this has become an essential part of evaluating diastolic function by echocardiography. In patients with a variety of cardiac diseases, the TDI parameters, especially E', were the most powerful predictors of cardiac death in the subsequent 2 years [4]. Even in the absence of clinical heart failure, left ventricular (LV) diastolic dysfunction (LVDD) is associated with increased rates of future hospitalizations, development of heart failure, and all-cause mortality [5]. Worsening stages of LVDD on echocardiography are associated with an incremental risk in adverse outcomes, including the development of clinical heart failure [6]. Accurately diagnosing LVDD could possibly lead to improved treatments and may have substantial health care implications, from both clinical and resource utilization perspectives.

Cardiac troponin $\mathrm{T}$ ( $\mathrm{cTnT}$ ) is the preferred biomarker for the diagnosis of acute myocardial infarction. Elevated troponin levels can be detected in clinical settings in which myocardial injuries occur, as well as in several chronic disease states, including patients with coronary artery disease (CAD), heart failure, and CKD [7-9]. A highly sensitive (hs) assay for cTnT has recently been developed, which determines concentrations that are lower by a factor of 10 than those measurable with conventional assays. In patients with chronic heart failure [10] and chronic CAD [11], circulating cTnT is detectable in almost all individuals with the highly sensitive assay, and higher levels correlate strongly with increased cardiovascular mortality. In patients with renal failure, conventionally assessed cTnT levels may be elevated simply owing to delayed cTnT clearance, but numerous studies have shown the strong prognostic significance of elevated troponin levels in patients with CKD $[9,12,13]$.

There have been several reports demonstrating that natriuretic peptides are a valuable tool that can be used to identify patients with severe diastolic dysfunction, however, they do not accurately predict mild or moderate diastolic dysfunction [14-16]. An elevation of B-type natriuretic peptide (BNP) may be a hallmark of diastolic heart failure, independent of LV hypertrophy (LVH) [17]. In patients with heart failure with a normal EF, concentric hypertrophy or remodeling can be observed. In addition, several studies have demonstrated an independent association between troponin levels and the presence of LVH in hemodialysis $[18,19]$, peritoneal dialysis [20], and non-dialysis-dependent CKD patients [12]. To date, no data are available regarding the usefulness of serum hs-cTnT as a diagnostic marker of LVDD 
in patients with non-dialysis CKD. We hypothesized that the serum hs-cTnT may be associated with LVDD, and investigated the relationship between hs-cTnT values and LVDD in CKD patients without clinically apparent heart failure.

\section{Patients and Methods}

\section{Patients}

Patients admitted to the Renal Unit of the Okayama University Hospital were included in this study. All patients were diagnosed as having CKD according to their estimated glomerular filtration rate (eGFR) and the presence of kidney injury as defined by National Kidney Foundation K/DOQI Guidelines [21, 22]. Patients with cardiogenic shock, congestive heart failure, valvular heart disease, acute coronary syndrome, and other malignancies were excluded. Patients with diabetic nephropathy or nephrotic syndrome were also excluded. Hypertension was defined as systolic blood pressure (SBP) $\geq 140 \mathrm{~mm} \mathrm{Hg}$ or diastolic blood pressure (DBP) $\geq 90 \mathrm{~mm} \mathrm{Hg}$, or the use of antihypertensive drugs. GFR was calculated according to the simplified version of the MDRD (Modification of Diet in Renal Disease) formula $\left[\mathrm{eGFR}=194 \times(\mathrm{sCr})^{-1.094} \times(\mathrm{age})^{-0.287}(\right.$ if female $\left.\times 0.739)\right]$ [23]. All procedures in the present study were carried out in accordance with the institutional and national ethical guidelines for human studies. The Ethical Committee of the Okayama University Graduate School of Medicine, Dentistry and Pharmaceutical Sciences approved the study. Informed consent was obtained from each subject. This study was registered with the Clinical Trial Registry of the University Hospital Medical Information Network (registration No. UMIN000003614).

\section{Laboratory Measurements}

After fasting overnight, arterial blood pressure was measured by a physician in the morning after a $10-\mathrm{min}$ rest period. The mean arterial pressure (MAP) was calculated as $\mathrm{DBP}+(\mathrm{SBP}-\mathrm{DBP}) / 3$. Serum and urine samples were obtained from patients in the morning after $12 \mathrm{~h}$ of fasting, and all parameters were measured immediately after blood sampling. In addition, aliquots were stored at $-80^{\circ} \mathrm{C}$ until assayed for serum hs-cTnT. Cystatin C concentrations were measured with the sol particle homogeneous immunoassay method (Nescauto GC Cystatin $C^{\circledR}$; Alfresa Pharma, Osaka, Japan) [24]. Plasma BNP was measured by a rapid test system using a fluorescence enzyme immunoassay [E test Tosoh II (BNP); Tosoh Medics, Tokyo, Japan]. Serum hs-cTnT was determined by the Elecsys ${ }^{\circledR} /$ cobas $^{\mathrm{TM}}$ cTnT 4 thgeneration assay (Roche Diagnostics) on the Elecsys 2010/cobas e411 and Modular ${ }^{\circledR}$ Analytics E170/cobas e601 immunoanalyzers (Roche Diagnostics) according to the instructions of the manufacturer $[11,25]$. The lower limit of detection of the hs-cTnT assay was $3.00 \mathrm{pg} / \mathrm{ml}$.

\section{Echocardiography}

Echocardiography was performed using a cardiac ultrasound unit with a 2- to $3.5-\mathrm{MHz}$ transducer. TDI was performed in all patients with images taken based on the guidelines of the American Society of Echocardiography [26]. LV end-diastolic/-systolic dimensions and end-diastolic/-systolic wall thickness of the interventricular septum and LV wall were determined using standard echocardiographic 2-D and M-mode measurements. Both EF and LV mass (LVM) were calculated from the M-mode echocardiogram. LVH was defined as the LVM index (LVMI) $>125 \mathrm{~g} / \mathrm{m}^{2}$ in males and $>110 \mathrm{~g} / \mathrm{m}^{2}$ in females. LVM was calculated according to the formula of Devereux et al. [27], using a correction factor of 0.8. Mitral inflow velocity was traced, and the following variables were derived: peak early (E) and late (A) transmitral flow velocities, and the ratio of early/late peak velocities (E/A). 
Tissue Doppler Imaging

A 6-mm sample volume at the septal corner of the mitral annulus was used for the apical four-chamber view. Annular velocities were displayed in spectral pulsed-wave TDI. The early peak diastolic annular velocity $\left(\mathrm{E}^{\prime}\right)$ was determined from the TDI recordings and the mitral $\mathrm{E} / \mathrm{E}^{\prime}$ ratio was calculated. $\mathrm{LV}$ filling pressure was considered to be elevated when $\mathrm{E} / \mathrm{E}^{\prime}>15$ and normal when $\mathrm{E} / \mathrm{E}^{\prime}<8$ [28]. Diastolic dysfunction was previously defined when $\mathrm{E}^{\prime}<8 \mathrm{~cm} / \mathrm{s}$ [29-31]. In this study, patients with LVDD with $\mathrm{E}^{\prime}<5 \mathrm{~cm} / \mathrm{s}$ were defined as having severe LVDD [32] because such patients had a worse prognosis than those with $\mathrm{E}^{\prime} \geq 5 \mathrm{~cm} / \mathrm{s}[4,33]$.

\section{Statistical Analysis}

Non-normally distributed variables were expressed as medians (interquartile ranges) and normally distributed variables as means $\pm S D$, as appropriate. $p<0.05$ was considered to be statistically significant. Variables showing a positively skewed distribution were natural logarithm transformed. Receiver-operating characteristic (ROC) curves were constructed to determine the optimal sensitivity and specificity, and the area under the curve (AUC) was calculated. Between-group comparisons were assessed for nominal variables with the $\chi^{2}$ test. Differences among the groups were analyzed by one-way ANOVA followed by a post hoc Tukey-Kramer test for multiple comparisons. Spearman's rank correlation was used to determine the correlations between two variables. A multivariate regression analysis was used to assess the predictors for $E^{\prime}$ and hs-cTnT. Statistical analysis was performed using the JMP software package release 8 (SAS Institute, Cary, N.C., USA).

\section{Results}

\section{Patient Characteristics}

After the first evaluation, 93 CKD patients with a mean age of $54 \pm 14$ years were included in the study. The causes of CKD are listed in table 1. A total of 62 patients were on antihypertensive therapy ( 52 patients were being treated with angiotensin receptor blockers, 10 with angiotensin-converting enzyme inhibitors, 37 with calcium channel antagonists, and 11 with other antihypertensive agents). Statins were administered to 19 patients and antiplatelet therapy to 20 patients. Based on their eGFR levels, patients were classified into stages 1-5 (table 1). Serum levels of biomarkers, including cystatin C, BNP, and hs-cTnT, were significantly elevated with increasing CKD stage. There were significant differences in the mean age, hemoglobin concentration, and LDL cholesterol among patients of different CKD stages. There were no significant differences in the MAP, daily albuminuria, serum albumin, $\mathrm{HDL}$ cholesterol, triglycerides, and $\mathrm{HbA}_{1 \mathrm{c}}$ among the CKD groups. Echocardiographic and TDI assessments revealed significant differences in the LVMI, E/A, E', and E/E' (table 1). There were no significant differences in EF or left atrial diameter among the groups (table 1). All patients demonstrated a normal LV systolic function.

An Increase in Serum hs-cTnT and a Decrease in LV Filling Pressure Are Associated with CKD Stage

Patients in stages 1-5 CKD without diabetes had gradually decreased $\mathrm{E}^{\prime}$ values $(\mathrm{p}<$ 0.0001 ; table 1). In addition, gradual increases in serum hs-cTnT levels were observed with increasing CKD stage ( $\mathrm{p}<0.0001$; table 1 ), with an average value of hs-cTnT in patients with eGFR $\geq 90$ of 3.56; eGFR 60-89 of 4.52; eGFR 30-59 of 6.86; eGFR 15-29 of 11.10, and eGFR $0-14 \mathrm{ml} / \mathrm{min} / 1.73 \mathrm{~m}^{2}$ of $20.41 \mathrm{pg} / \mathrm{ml}$. The highest hs-cTnT concentration was found in patients in stage $5 \mathrm{CKD}$. 
Table 1. Baseline characteristics of the study patients

\begin{tabular}{|c|c|c|c|c|c|c|c|}
\hline & \multicolumn{6}{|l|}{ CKD stage } & \multirow{2}{*}{$\begin{array}{l}\mathrm{p} \\
\text { value }\end{array}$} \\
\hline & $\begin{array}{l}1 \\
(\mathrm{n}=11)\end{array}$ & $\begin{array}{l}2 \\
(\mathrm{n}=30)\end{array}$ & $\begin{array}{l}3 \\
(n=23)\end{array}$ & $\begin{array}{l}4 \\
(n=15)\end{array}$ & $\begin{array}{l}5 \\
(\mathrm{n}=14)\end{array}$ & $\begin{array}{l}\text { total } \\
(\mathrm{n}=93)\end{array}$ & \\
\hline Age, years & $33 \pm 7$ & $49 \pm 14$ & $61 \pm 9$ & $64 \pm 9$ & $57 \pm 12$ & $54 \pm 14$ & $<0.0001$ \\
\hline Gender, males/females & $3 / 8$ & $17 / 13$ & $12 / 11$ & $10 / 5$ & $8 / 6$ & $50 / 43$ & \\
\hline \multicolumn{8}{|l|}{ Cause of CKD, n } \\
\hline Glomerulonephritis & 10 & 21 & 16 & 1 & 3 & 51 & \\
\hline Nephrosclerosis & 0 & 7 & 5 & 11 & 5 & 28 & \\
\hline Other & 1 & 2 & 2 & 3 & 6 & 14 & \\
\hline \multicolumn{8}{|l|}{ Current medication, $\mathrm{n}$} \\
\hline ARBs/ACEIs & 1 & 10 & 18 & 12 & 11 & 52 & \\
\hline CCBs & 0 & 8 & 12 & 8 & 9 & 37 & \\
\hline MAP, mm Hg & $86 \pm 10$ & $91 \pm 11$ & $93 \pm 11$ & $93 \pm 13$ & $96 \pm 10$ & $92 \pm 11$ & 0.1952 \\
\hline $\mathrm{eGFR}, \mathrm{ml} / \mathrm{min} / 1.73 \mathrm{~m}^{2}$ & $102 \pm 9$ & $72 \pm 9$ & $45 \pm 9$ & $23 \pm 4$ & $11 \pm 3$ & $52 \pm 3$ & $<0.0001$ \\
\hline Albuminuria, mg/day & $123(17-597)$ & $297(147-704)$ & $123(48-864)$ & $418(92-1,209)$ & $620(153-1,496)$ & $289(99-821)$ & 0.1959 \\
\hline Cystatin C, mg/dl & $0.8 \pm 0.1$ & $1.0 \pm 0.2$ & $1.4 \pm 0.3$ & $2.5 \pm 0.4$ & $3.7 \pm 0.7$ & $1.8 \pm 1.1$ & $<0.0001$ \\
\hline Serum albumin, $\mathrm{g} / \mathrm{dl}$ & $4.2 \pm 0.3$ & $3.9 \pm 0.6$ & $3.9 \pm 0.4$ & $3.8 \pm 0.4$ & $3.9 \pm 0.5$ & $3.9 \pm 0.5$ & 0.2827 \\
\hline Hemoglobin, g/dl & $13.7 \pm 1.5$ & $14.1 \pm 1.8$ & $12.3 \pm 1.6$ & $11.0 \pm 1.5$ & $11.0 \pm 1.9$ & $12.6 \pm 2.1$ & $<0.0001$ \\
\hline LDL cholesterol, mg/dl & $104 \pm 38$ & $129 \pm 30$ & $113 \pm 26$ & $104 \pm 30$ & $104 \pm 27$ & $114 \pm 30$ & 0.0226 \\
\hline HDL cholesterol, mg/dl & $60 \pm 19$ & $56 \pm 16$ & $52 \pm 16$ & $50 \pm 18$ & $47 \pm 13$ & $53 \pm 17$ & 0.2324 \\
\hline Triglycerides, mg/dl & $77(75-139)$ & $129(89-181)$ & $109(84-174)$ & $132(86-190)$ & $122(72-185)$ & $119(79-171)$ & 0.6931 \\
\hline $\mathrm{HbA}_{1 \mathrm{c}}, \%$ & $5.2 \pm 0.5$ & $5.3 \pm 0.4$ & $5.4 \pm 0.3$ & $5.3 \pm 0.3$ & $5.4 \pm 0.5$ & $5.3 \pm 0.4$ & 0.3227 \\
\hline $\mathrm{BNP}, \mathrm{pg} / \mathrm{ml}$ & $9(7-16)$ & $19(5-33)$ & $15(8-32)$ & $34(21-68)$ & $29(9-53)$ & $19(9-42)$ & 0.0473 \\
\hline hs-cTnT, pg/ml & 3 & $3(3-4)$ & $5(3-9)$ & $9(7-16)$ & $16(8.5-27)$ & $4(3-9)$ & $<0.0001$ \\
\hline $\mathrm{EF}, \%$ & $68 \pm 6$ & $70 \pm 6$ & $68 \pm 6$ & $70 \pm 9$ & $68 \pm 6$ & $69 \pm 7$ & 0.8585 \\
\hline LVMI, $\mathrm{g} / \mathrm{m}^{2}$ & $71 \pm 20$ & $90 \pm 21$ & $92 \pm 20$ & $115 \pm 36$ & $111 \pm 43$ & $96 \pm 30$ & 0.0019 \\
\hline $\mathrm{LAD}, \mathrm{mm}$ & $34 \pm 7$ & $34 \pm 5$ & $34 \pm 5$ & $38 \pm 6$ & $35 \pm 6$ & $35 \pm 6$ & 0.1761 \\
\hline $\mathrm{E} / \mathrm{A}$ & $1.6(1.1-2.3)$ & $1.0(0.9-1.5)$ & $0.9(0.8-1.1)$ & $0.8(0.7-1.0)$ & $0.9(0.7-1.0)$ & $0.9(0.8-1.2)$ & $<0.0001$ \\
\hline $\mathrm{E}^{\prime}, \mathrm{cm} / \mathrm{s}$ & $11.0 \pm 3.1$ & $8.9 \pm 2.1$ & $7.1 \pm 2.4$ & $6.2 \pm 1.8$ & $7.0 \pm 2.4$ & $7.8 \pm 2.6$ & $<0.0001$ \\
\hline $\mathrm{E} / \mathrm{E}^{\prime}$ & $7.6 \pm 2.1$ & $7.8 \pm 21.9$ & $9.6 \pm 2.7$ & $10.2 \pm 2.7$ & $8.8 \pm 2.6$ & $8.9 \pm 2.6$ & 0.0160 \\
\hline
\end{tabular}

Non-normally distributed variables are expressed as medians (interquartile ranges) and normally distributed variables as means \pm SD. $\mathrm{ACEI}=$ Angiotensin-converting enzyme inhibitor; $\mathrm{ARB}=$ angiotensin receptor blocker; $\mathrm{CCB}=$ calcium channel blocker; $\mathrm{LAD}=$ left atrial diameter.

\section{Serum hs-cTnT Correlates with Cardiorenal Markers}

In univariate analysis, serum $\ln$ hs-cTnT levels correlated negatively with $\mathrm{E}^{\prime}(\mathrm{r}=-0.5104$, $\mathrm{p}<0.0001$; table 2$)$, but were positively associated with daily albuminuria $(\mathrm{r}=0.2574, \mathrm{p}=$ $0.0341)$, serum cystatin C $(\mathrm{r}=0.7751, \mathrm{p}<0.0001)$, MAP $(\mathrm{r}=0.3460, \mathrm{p}=0.0018)$, and LVMI $(\mathrm{r}=0.5195, \mathrm{p}<0.0001$; table 2).

Serum hs-cTnT and Plasma BNP Significantly Increase in CKD Patients with $E^{\prime}<5 \mathrm{~cm} / \mathrm{s}$

The non-diabetic CKD patients with severe LVDD detected by $E^{\prime}<5 \mathrm{~cm} / \mathrm{s}$ had significantly higher serum hs-cTnT levels compared to those with $\mathrm{E}^{\prime} \geq 5 \mathrm{~cm} / \mathrm{s}$ (fig. 1a). The average value of hs-cTnT was $7.4 \pm 8.3 \mathrm{pg} / \mathrm{ml}$ in CKD patients with $\mathrm{E}^{\prime} \geq 5 \mathrm{~cm} / \mathrm{s}$, whereas it was 17.0 $\pm 7.3 \mathrm{pg} / \mathrm{ml}$ in those with $\mathrm{E}^{\prime}<5 \mathrm{~cm} / \mathrm{s}$. There were significant differences in plasma BNP, another biomarker of heart failure, between CKD patients with $E^{\prime} \geq 5 \mathrm{~cm} / \mathrm{s}$ and those with $\mathrm{E}^{\prime}<5 \mathrm{~cm} / \mathrm{s}$ (fig. $1 \mathrm{~b}$ ).

The ability of using hs-cTnT to detect $\mathrm{E}^{\prime}<5 \mathrm{~cm} / \mathrm{s}$ in patients with normal systolic function was assessed by ROC analysis (fig. 2). The AUC for the ROC curve when hs-cTnT was used to detect $E^{\prime}<5 \mathrm{~cm} / \mathrm{s}$ was $0.880(\mathrm{p}=0.0101)$, which denoted moderate accuracy. A hs- 
Fig. 1. The distribution of hscTnT (a) and BNP (b) in CKD patients with or without severe LVDD. $\mathbf{a} \mathrm{n}=66$ in the $\mathrm{E}^{\prime} \geq 5 \mathrm{~cm} / \mathrm{s}$ group and $\mathrm{n}=10$ in the $\mathrm{E}^{\prime}<5$ $\mathrm{cm} / \mathrm{s}$ group. $\mathbf{b} \mathrm{n}=68$ in the $\mathrm{E}^{\prime} \geq 5$ $\mathrm{cm} / \mathrm{s}$ group and $\mathrm{n}=10$ in the $\mathrm{E}^{\prime}$ $<5 \mathrm{~cm} / \mathrm{s}$ group. Severe LVDD was defined as $\mathrm{E}^{\prime}<5 \mathrm{~cm} / \mathrm{s}$ by TDI.
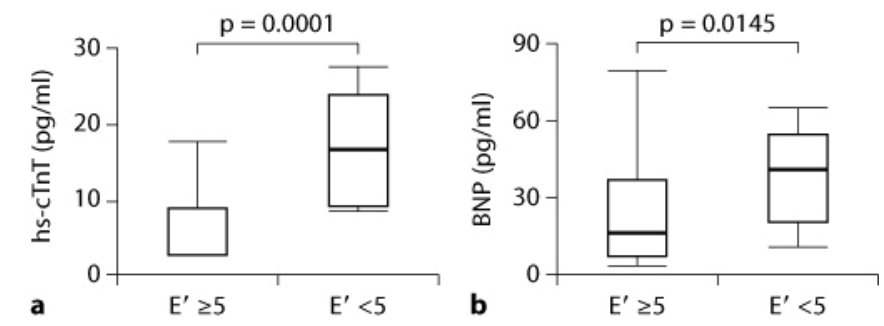

Table 2. Univariate relationships of clinical and echocardiographic indices to $\ln$ hs-cTnT

\begin{tabular}{lrr}
\hline & r value & p value \\
\hline Age & 0.4765 & $<0.0001$ \\
MAP & 0.3460 & 0.0018 \\
eGFR & -0.6867 & $<0.0001$ \\
Albuminuria & 0.2574 & 0.0341 \\
Cystatin C & 0.7751 & $<0.0001$ \\
Serum albumin & -0.1253 & 0.2496 \\
Hemoglobin & -0.4221 & 0.0001 \\
LDL cholesterol & -0.1754 & 0.1246 \\
HDL cholesterol & -0.4361 & $<0.0001$ \\
Triglycerides & 0.1254 & 0.2739 \\
HbA & 0.2593 & 0.0228 \\
BNP & 0.2178 & 0.0661 \\
EF & -0.0301 & 0.7964 \\
LVMI & 0.5195 & $<0.0001$ \\
LAD & 0.3322 & 0.0034 \\
E/A & -0.4311 & 0.0001 \\
E $^{\prime}$ & -0.5104 & $<0.0001$ \\
E/E' & 0.3363 & 0.0032 \\
\hline
\end{tabular}

LAD = Left atrial diameter.

cTnT value of $9 \mathrm{pg} / \mathrm{ml}$ had a sensitivity of $100 \%$, and a specificity of $76 \%$ (fig. 2a). The AUC for the ROC curve when BNP was used to detect $\mathrm{E}^{\prime}<5 \mathrm{~cm} / \mathrm{s}$ was $0.741(\mathrm{p}=0.0570)$, which also denoted a moderate degree of accuracy. A BNP value of $20.3 \mathrm{pg} / \mathrm{ml}$ had a sensitivity of $90 \%$, and a specificity of $57 \%$ (fig. 2b). The AUC for hs-cTnT was therefore greater than that for BNP.

\section{Multiple Regression Analysis for $E^{\prime}$ and $h s-c T n T$}

Table 3 presents separate multiple regression models for $\mathrm{E}^{\prime}$ and hs-cTnT. After adjustment for age and the cause of CKD, the variable expected to influence $E^{\prime}$ was hs-cTnT in the biomarker-based model, and albuminuria in the CKD-based model (table 3a). Moreover, the factor expected to influence hs-cTnT was eGFR in the CKD-based model (table 3b). 


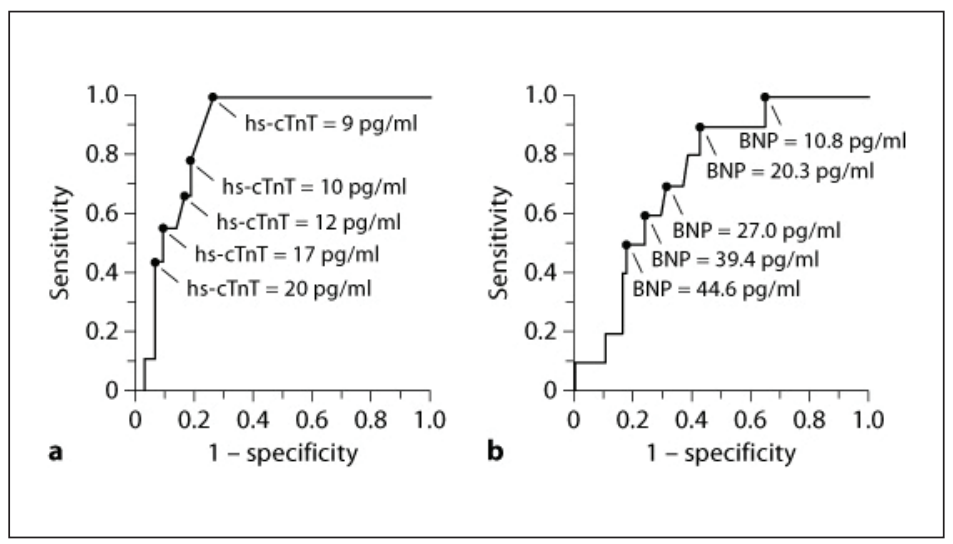

Fig. 2. ROC curve comparing sensitivity and specificity of hs-cTnT (a) and BNP (b) for detecting LVDD with $\mathrm{E}^{\prime}<5 \mathrm{~cm} / \mathrm{s}$ by echocardiography. The AUC for the ROC curve where hs-cTnT was used to detect $\mathrm{E}^{\prime}<5 \mathrm{~cm} / \mathrm{s}$ was $0.880(\mathrm{p}=0.0101)$. A hs-cTnT value of $9 \mathrm{pg} / \mathrm{ml}$ had a sensitivity of $100 \%$, and a specificity of $76 \%$. The AUC for the ROC curve where BNP was used to detect $\mathrm{E}^{\prime}<5 \mathrm{~cm} / \mathrm{s}$ was 0.741 ( $\left.\mathrm{p}=0.0570\right)$. A BNP value of $20.3 \mathrm{pg} / \mathrm{ml}$ had a sensitivity of $90 \%$, and a specificity of $57 \%$.

Table 3. Multivariate regression analysis of predictors of $\mathrm{E}^{\prime}(\mathbf{a})$ and hs-cTnT (b)

\begin{tabular}{lrr}
\hline & $\beta$ & $\mathrm{p}$ \\
\hline a $E^{\prime}$ (adjusted for age and cause of CKD) & & \\
Echocardiography-based model & & \\
$\quad$ MAP & -0.040599 & 0.0452 \\
EF & 0.022496 & 0.4741 \\
LVMI & -0.010729 & 0.1900 \\
Biomarker-based model & & \\
$\quad$ hs-cTnT & -0.058090 & 0.0332 \\
BNP & 0.001469 & 0.8214 \\
CKD-based model & & \\
$\quad$ eGFR & 0.007911 & 0.3771 \\
$\quad$ Albuminuria & -0.000723 & 0.0154 \\
\hline b hs-cTnT (adjusted for age and cause of CKD) & \\
Echocardiography-based model & & \\
MAP & 0.142268 & 0.1511 \\
EF & 0.147041 & 0.3180 \\
E' & -0.888941 & 0.0845 \\
CKD-based model & & \\
$\quad$ eGFR & -0.160545 & $<0.0001$ \\
Albuminuria & -0.000015 & 0.9907 \\
\hline
\end{tabular}

\section{Discussion}

In our study, we investigated the relationship between serum hs-cTnT and LVDD in patients with CKD and demonstrated that CKD patients with $\mathrm{E}^{\prime}<5 \mathrm{~cm} / \mathrm{s}$ had significantly higher serum hs-cTnT levels compared to those with $E^{\prime} \geq 5 \mathrm{~cm} / \mathrm{s}$. The AUC for the ROC curve using hs-cTnT to detect $\mathrm{E}^{\prime}<5 \mathrm{~cm} / \mathrm{s}$ was 0.880 , which denoted moderate accuracy. Our data suggest that, in addition to plasma BNP, the recently established serum hs-cTnT value may therefore be associated with LVDD in CKD patients. In multivariate analysis, hs-cTnT and albuminuria were significant predictors of $\mathrm{E}^{\prime}$ in the biomarker-based model and the 
CKD-based model, respectively, and eGFR was significantly associated with hs-cTnT after adjusting for age and the etiology of kidney disease in non-diabetic CKD patients.

The cTnT concentration measured with a hs-cTnT assay is a prognostic factor for the incidence of cardiovascular death and heart failure in patients with stable chronic heart failure [10], with stable CAD [11], in the general population with a younger age [34], and in senior adults [8]. Our study demonstrated that CKD patients with LVDD indicated by an $\mathrm{E}^{\prime}$ value $<5 \mathrm{~cm} / \mathrm{s}$ had significantly higher hs-cTnT levels compared to those with $\mathrm{E}^{\prime} \geq 5 \mathrm{~cm} / \mathrm{s}$. The median value of serum hs-cTnT was $17.0 \mathrm{pg} / \mathrm{ml}$ in CKD patients with LVDD with $\mathrm{E}^{\prime}<5$ $\mathrm{cm} / \mathrm{s}$, and this value corresponded to quartile 4 , which has been reported to have the highest cumulative incidence of cardiovascular death [11]. In our study, the difference in the ln hscTnT between patients with $\mathrm{E}^{\prime}<5$ and $\mathrm{E}^{\prime} \geq 5 \mathrm{~cm} / \mathrm{s}$ was 1.08 units. The adjusted hazard ratio per unit increase in the natural logarithm of hs-cTnT of the cumulative incidence of cardiovascular death and heart failure was 2.09 and 2.20, respectively [11]. Thus, the hs-cTnT level in patients with LVDD indicated by $E^{\prime}<5 \mathrm{~cm} / \mathrm{s}$ in this study was substantially higher, which may be sufficient to cause cardiovascular events in CKD patients. Our findings provide valuable insight into the relationship between hs-cTnT and LVDD with $\mathrm{E}^{\prime}<5 \mathrm{~cm} / \mathrm{s}$. We reported the performance of hs-cTnT for the detection of LVDD with $\mathrm{E}^{\prime}<5 \mathrm{~cm} / \mathrm{s}$ in patients to have a moderate degree of accuracy (AUC $=0.880$ ). However, the AUC for hs-cTnT was greater than that for BNP.

Persistently elevated cardiac troponin is frequently observed among patients with endstage renal disease $[9,35]$. The prevalence of increased troponin values among patients with chronic renal failure in the absence of clinically suspected ischemia, such as in our study, may be the result of small areas of clinically silent myocardial necrosis. However, other causes, such as increased LVM and impaired renal troponin excretion, have also been proposed [36]. cTnT has a molecular weight of $37 \mathrm{kDa}$ and that of cTnI (cardiac troponin I) is $22.5 \mathrm{kDa}$. cTnI is released from the cell in complexes of TnT-I-C (77 kDa) and TnI-C (40 $\mathrm{kDa}$ ), while cTnT is released as free TnT or TnT-I-C complexes [35]. Recent studies have shown that both cTnT and cTnI are degraded in myocardial cells, and then released as small molecules that are still detected by the assays [37,38]. Diris et al. [37] demonstrated that cTnT is split into fragments that range in size from 8 to $25 \mathrm{kDa}$, even in samples with measured cTnT concentrations that are $<10 \mathrm{pg} / \mathrm{ml}$. These fragments are small enough to be cleared by the kidneys, and therefore could be elevated in patients with renal failure owing to delayed clearance. In contrast, Fahie-Wilson et al. [39] and Bates et al. [40] reported that the form of cTnT observed in the serum of patients with kidney failure is predominantly the free intact form, and there is no evidence of cTnT fragments existing in the circulation. Their data are consistent with the view that circulating cTnT in renal failure patients reflects cardiac injury.

$\mathrm{CKD}$ is an increasing public health problem [41]. Cardiovascular disease is frequently associated with CKD, which is important, since individuals with CKD are more likely to die of cardiovascular disease than to develop kidney failure. Indeed, the term cardiorenal syndrome has been increasingly used, and a new classification was proposed because a large proportion of patients admitted to the hospital have various degrees of heart and kidney dysfunction [42]. In our cohort, 48 patients (57\%) had $\mathrm{E}^{\prime}<8 \mathrm{~cm} / \mathrm{s}$ and 10 patients $(12 \%)$ had $\mathrm{E}^{\prime}<5 \mathrm{~cm} / \mathrm{s}$. $\mathrm{E}^{\prime}$ was significantly decreased with increasing CKD stage, and eGFR showed a significant association with $\mathrm{E}^{\prime}<5 \mathrm{~cm} / \mathrm{s}$. LVDD is very common among CKD patients and may be associated with the subsequent development of heart failure and mortality [43]. In patients with heart failure, the presence of CKD is associated with a worse diastolic function, intracardiac conduction and prognosis $[2,33]$. An impairment in the diastolic function in patients with CKD may occur very early, even in the absence of LVH [44]. In hypertensive patients in stage 2-5 $\mathrm{CKD}$, who are free of cardiovascular disease, $\mathrm{E}^{\prime}$ evaluated by TDI was lower with lessening renal function, with very low values in stage $5 \mathrm{CKD}$, although all patients were free from heart 
failure [44]. E' has been demonstrated to be inversely related to the degree of fibrosis in ischemic, as well as normal, myocardial segments [45]. Although the pathogenesis of LVH in CKD patients is considered to be multifactorial, hypertension, alterations in fluid and electrolyte balance, and anemia are identified as the major determinants of LV growth in CKD patients. However, beyond hemodynamic factors, other factors, e.g. inappropriate activation of the renin-angiotensin-aldosterone system, oxidative stress, inflammation and hyperactivation of collagen and muscle cell growth factors, may also play a role in LV growth in CKD.

In this study, albuminuria was the most significant predictor of $E^{\prime}$ in non-diabetic CKD patients. An association of albuminuria with systolic and diastolic LV dysfunction in diabetic cardiomyopathy in type 2 diabetic patients was previously reported [46]. The mechanism underlying the relationship between LVDD and albuminuria is unclear. In the present study, SBP and pulse pressure were both significantly higher in patients with $\mathrm{E}^{\prime}<5 \mathrm{~cm} / \mathrm{s}$ than in those with $E^{\prime} \geq 5 \mathrm{~cm} / \mathrm{s}(\mathrm{p}<0.001)$. Since systemic hypertension could cause glomerular hypertension and hyperfiltration, which leads to albuminuria, it may represent a candidate mechanism responsible for the relationship between LVDD and albuminuria. LVDD may cause volume overload of circulating plasma, thus leading to an increase in renal blood flow. Diastolic dysfunction might be associated with albuminuria via endothelial dysfunction. An impairment in tubular reabsorption of albumin may be one of the causes of albuminuria [47]. Several molecules, including heart-type fatty acid binding proteins, can be synthesized by both cardiomyocytes and distal tubular epithelial cells in the kidneys, so that simultaneous dysfunction of the heart and kidney might occur in CKD patients.

\section{Study Limitations}

Several limitations of this study should be noted. First, our sample size is relatively small, and a larger cohort of CKD patients will need to be examined to confirm our findings. Second, given that these results are cross-sectional, we may not draw definitive inferences on their direction or causality. Third, because of the multifactorial causes of diastolic dysfunction, it is possible that we did not fully control for all confounding variables, such as factors for mineral metabolism and vascular parameters.

\section{Conclusion}

Among patients with non-diabetic CKD without LV systolic dysfunction who are at increased risk for cardiovascular events, the serum hs-cTnT may be a significant biomarker for LVDD. Further investigation, including an outcome study elucidating the significance of hscTnT as a prognostic factor, should be performed in a prospective study in the near future.

\section{Acknowledgments}

We thank Ms. M. Hada, H. Tsuji, and S. Kameshima for their technical assistance. We also extend our gratitude to Dr. K. Kusano (Department of Cardiovascular Medicine) for helpful advice and to doctors in the Department of Medicine and Clinical Science, Okayama University Graduate School, for the collection of blood and urine samples.

Part of this study was supported by research grants from the Kidney Foundation Japan (JKFB10-20 to M.K.), the Japanese Vascular Disease Research Foundation (to H.S.) and a Grant-in-Aid for Research on Progressive Renal and Intractable Diseases from the Ministry of Health, Labor and Welfare of Japan. 
Kitagawa et al.: hs-cTnT and LVDD in CKD

\section{Disclosure Statement}

All of the authors declare that they have no competing interests.

\section{References}

1 Owan TE, Hodge DO, Herges RM, Jacobsen SJ, Roger VL, Redfield MM: Trends in prevalence and outcome of heart failure with preserved ejection fraction. N Engl J Med 2006;355:251-259.

2 Ahmed A, Rich MW, Sanders PW, Perry GJ, Bakris GL, Zile MR, Love TE, Aban IB, Shlipak MG: Chronic kidney disease associated mortality in diastolic versus systolic heart failure: a propensity matched study. Am J Cardiol 2007;99:393-398.

3 Paulus WJ, Tschope C, Sanderson JE, Rusconi C, Flachskampf FA, Rademakers FE, Marino P, Smiseth OA, De Keulenaer G, Leite-Moreira AF, Borbely A, Edes I, Handoko ML, Heymans S, Pezzali N, Pieske B, Dickstein K, Fraser AG, Brutsaert DL: How to diagnose diastolic heart failure: a consensus statement on the diagnosis of heart failure with normal left ventricular ejection fraction by the heart failure and echocardiography associations of the European Society of Cardiology. Eur Heart J 2007;28:2539-2550.

4 Wang M, Yip GW, Wang AY, Zhang Y, Ho PY, Tse MK, Lam PK, Sanderson JE: Peak early diastolic mitral annulus velocity by tissue Doppler imaging adds independent and incremental prognostic value. J Am Coll Cardiol 2003;41:820-826.

5 Tsutsui $\mathrm{H}$, Tsuchihashi M, Takeshita A: Mortality and readmission of hospitalized patients with congestive heart failure and preserved versus depressed systolic function. Am J Cardiol 2001;88:530-533.

6 Redfield MM, Jacobsen SJ, Burnett JC Jr, Mahoney DW, Bailey KR, Rodeheffer RJ: Burden of systolic and diastolic ventricular dysfunction in the community: appreciating the scope of the heart failure epidemic. JAMA 2003;289:194-202.

7 Eggers KM, Lagerqvist B, Venge P, Wallentin L, Lindahl B: Persistent cardiac troponin I elevation in stabilized patients after an episode of acute coronary syndrome predicts long-term mortality. Circulation 2007;116:1907-1914.

8 deFilippi CR, de Lemos JA, Christenson RH, Gottdiener JS, Kop WJ, Zhan M, Seliger SL: Association of serial measures of cardiac troponin $\mathrm{T}$ using a sensitive assay with incident heart failure and cardiovascular mortality in older adults. JAMA 2010;304:2494-2502.

9 Apple FS, Murakami MM, Pearce LA, Herzog CA: Predictive value of cardiac troponin I and T for subsequent death in end-stage renal disease. Circulation 2002;106:2941-2945.

10 Latini R, Masson S, Anand IS, Missov E, Carlson M, Vago T, Angelici L, Barlera S, Parrinello G, Maggioni AP, Tognoni G, Cohn JN: Prognostic value of very low plasma concentrations of troponin T in patients with stable chronic heart failure. Circulation 2007;116:1242-1249.

11 Omland T, de Lemos JA, Sabatine MS, Christophi CA, Rice MM, Jablonski KA, Tjora S, Domanski MJ, Gersh BJ, Rouleau JL, Pfeffer MA, Braunwald E: A sensitive cardiac troponin T assay in stable coronary artery disease. N Engl J Med 2009;361:2538-2547.

12 Lamb EJ, Kenny C, Abbas NA, John RI, Webb MC, Price CP, Vickery S: Cardiac troponin I concentration is commonly increased in nondialysis patients with CKD: experience with a sensitive assay. Am J Kidney Dis 2007;49:507-516.

13 Khan NA, Hemmelgarn BR, Tonelli M, Thompson CR, Levin A: Prognostic value of troponin T and I among asymptomatic patients with end-stage renal disease: a meta-analysis. Circulation 2005;112: 3088-3096.

14 Redfield MM, Rodeheffer RJ, Jacobsen SJ, Mahoney DW, Bailey KR, Burnett JC Jr: Plasma brain natriuretic peptide to detect preclinical ventricular systolic or diastolic dysfunction: a communitybased study. Circulation 2004;109:3176-3181.

15 Abhayaratna WP, Marwick TH, Becker NG, Jeffery IM, McGill DA, Smith WT: Population-based detection of systolic and diastolic dysfunction with amino-terminal pro-B-type natriuretic peptide. Am Heart J 2006;152:941-948.

16 Luers C, Wachter R, Kleta S, Uhlir M, Koschack J, Scherer M, Binder L, Herrmann-Lingen C, Zapf A, Kulle B, Kochen MM, Pieske B: Natriuretic peptides in the detection of preclinical diastolic or systolic dysfunction. Clin Res Cardiol 2010;99:217-226. 
17 Yamaguchi H, Yoshida J, Yamamoto K, Sakata Y, Mano T, Akehi N, Hori M, Lim YJ, Mishima M, Masuyama T: Elevation of plasma brain natriuretic peptide is a hallmark of diastolic heart failure independent of ventricular hypertrophy. J Am Coll Cardiol 2004;43:55-60.

18 Mallamaci F, Zoccali C, Parlongo S, Tripepi G, Benedetto FA, Cutrupi S, Bonanno G, Fatuzzo P, Rapisarda F, Seminara G, Stancanelli B, Bellanuova I, Cataliotti A, Malatino LS: Diagnostic value of troponin $\mathrm{T}$ for alterations in left ventricular mass and function in dialysis patients. Kidney Int 2002; 62:1884-1890.

19 Iliou MC, Fumeron C, Benoit MO, Tuppin P, Courvoisier CL, Calonge VM, Moatti N, Buisson C, Jacquot C: Factors associated with increased serum levels of cardiac troponins $\mathrm{T}$ and $\mathrm{I}$ in chronic haemodialysis patients: chronic haemodialysis and new cardiac markers evaluation (CHANCE) study. Nephrol Dial Transplant 2001;16:1452-1458.

20 Duman D, Tokay S, Toprak A, Oktay A, Ozener IC, Unay O: Elevated cardiac troponin T is associated with increased left ventricular mass index and predicts mortality in continuous ambulatory peritoneal dialysis patients. Nephrol Dial Transplant 2005;20:962-967.

$21 \mathrm{~K} / \mathrm{DOQI}$ clinical practice guidelines on hypertension and antihypertensive agents in chronic kidney disease. Am J Kidney Dis 2004;43:S1-S290.

22 Imai E, Horio M, Nitta K, Yamagata K, Iseki K, Hara S, Ura N, Kiyohara Y, Hirakata H, Watanabe T, Moriyama T, Ando Y, Inaguma D, Narita I, Iso H, Wakai K, Yasuda Y, Tsukamoto Y, Ito S, Makino H, Hishida A, Matsuo S: Estimation of glomerular filtration rate by the MDRD study equation modified for Japanese patients with chronic kidney disease. Clin Exp Nephrol 2007;11:41-50.

23 Matsuo S, Imai E, Horio M, Yasuda Y, Tomita K, Nitta K, Yamagata K, Tomino Y, Yokoyama H, Hishida A: Revised equations for estimated GFR from serum creatinine in Japan. Am J Kidney Dis 2009;53:982-992.

24 Tanaka M, Matsuo K, Enomoto M, Mizuno K: A sol particle homogeneous immunoassay for measuring serum cystatin C. Clin Biochem 2004;37:27-35.

25 Giannitsis E, Kurz K, Hallermayer K, Jarausch J, Jaffe AS, Katus HA: Analytical validation of a highsensitivity cardiac troponin T assay. Clin Chem 2009;56:254-261.

26 Schiller NB, Shah PM, Crawford M, DeMaria A, Devereux R, Feigenbaum H, Gutgesell H, Reichek N, Sahn D, Schnittger I, et al: Recommendations for quantitation of the left ventricle by two-dimensional echocardiography. American Society of Echocardiography Committee on Standards, Subcommittee on Quantitation of Two-Dimensional Echocardiograms. J Am Soc Echocardiogr 1989;2: 358-367.

27 Devereux RB, Alonso DR, Lutas EM, Gottlieb GJ, Campo E, Sachs I, Reichek N: Echocardiographic assessment of left ventricular hypertrophy: comparison to necropsy findings. Am J Cardiol 1986;57: $450-458$.

28 Ommen SR, Nishimura RA, Appleton CP, Miller FA, Oh JK, Redfield MM, Tajik AJ: Clinical utility of Doppler echocardiography and tissue Doppler imaging in the estimation of left ventricular filling pressures: a comparative simultaneous Doppler-catheterization study. Circulation 2000;102:17881794.

29 Nagueh SF, Middleton KJ, Kopelen HA, Zoghbi WA, Quinones MA: Doppler tissue imaging: a noninvasive technique for evaluation of left ventricular relaxation and estimation of filling pressures. J Am Coll Cardiol 1997;30:1527-1533.

30 Kasner M, Westermann D, Steendijk P, Gaub R, Wilkenshoff U, Weitmann K, Hoffmann W, Poller W, Schultheiss HP, Pauschinger M, Tschope C: Utility of Doppler echocardiography and tissue Doppler imaging in the estimation of diastolic function in heart failure with normal ejection fraction: a comparative Doppler-conductance catheterization study. Circulation 2007;116:637-647.

31 Garcia MJ, Thomas JD, Klein AL: New Doppler echocardiographic applications for the study of diastolic function. J Am Coll Cardiol 1998;32:865-875.

32 Lester SJ, Tajik AJ, Nishimura RA, Oh JK, Khandheria BK, Seward JB: Unlocking the mysteries of diastolic function: deciphering the rosetta stone 10 years later. J Am Coll Cardiol 2008;51:679-689.

33 Bruch C, Rothenburger M, Gotzmann M, Wichter T, Scheld HH, Breithardt G, Gradaus R: Chronic kidney disease in patients with chronic heart failure - impact on intracardiac conduction, diastolic function and prognosis. Int J Cardiol 2007;118:375-380.

34 de Lemos JA, Drazner MH, Omland T, Ayers CR, Khera A, Rohatgi A, Hashim I, Berry JD, Das SR, Morrow DA, McGuire DK: Association of troponin T detected with a highly sensitive assay and cardiac structure and mortality risk in the general population. JAMA 2010;304:2503-2512. 
35 Freda BJ, Tang WH, Van Lente F, Peacock WF, Francis GS: Cardiac troponins in renal insufficiency: review and clinical implications. J Am Coll Cardiol 2002;40:2065-2071.

36 Jeremias A, Gibson CM: Narrative review: alternative causes for elevated cardiac troponin levels when acute coronary syndromes are excluded. Ann Intern Med 2005;142:786-791.

37 Diris JH, Hackeng CM, Kooman JP, Pinto YM, Hermens WT, van Dieijen-Visser MP: Impaired renal clearance explains elevated troponin T fragments in hemodialysis patients. Circulation 2004;109: $23-25$.

38 Michielsen EC, Diris JH, Kleijnen VW, Wodzig WK, Van Dieijen-Visser MP: Investigation of release and degradation of cardiac troponin $\mathrm{T}$ in patients with acute myocardial infarction. Clin Biochem 2007; $40: 851-855$.

39 Fahie-Wilson MN, Carmichael DJ, Delaney MP, Stevens PE, Hall EM, Lamb EJ: Cardiac troponin T circulates in the free, intact form in patients with kidney failure. Clin Chem 2006;52:414-420.

40 Bates KJ, Hall EM, Fahie-Wilson MN, Kindler H, Bailey C, Lythall D, Lamb EJ: Circulating immunoreactive cardiac troponin forms determined by gel filtration chromatography after acute myocardial infarction. Clin Chem 2010;56:952-958.

41 Sarnak MJ, Levey AS, Schoolwerth AC, Coresh J, Culleton B, Hamm LL, McCullough PA, Kasiske BL, Kelepouris E, Klag MJ, Parfrey P, Pfeffer M, Raij L, Spinosa DJ, Wilson PW: Kidney disease as a risk factor for development of cardiovascular disease: a statement from the American Heart Association Councils on Kidney in Cardiovascular Disease, High Blood Pressure Research, Clinical Cardiology, and Epidemiology and Prevention. Circulation 2003;108:2154-2169.

42 Ronco C, Haapio M, House A, Anavekar N, Bellomo R: Cardiorenal syndrome. J Am Coll Cardiol 2008;52:1527-1539.

43 London GM: Left ventricular alterations and end-stage renal disease. Nephrol Dial Transplant 2002; 17(suppl 1):29-36.

44 Nardi E, Cottone S, Mule G, Palermo A, Cusimano P, Cerasola G: Influence of chronic renal insufficiency on left ventricular diastolic function in hypertensives without left ventricular hypertrophy. J Nephrol 2007;20:320-328.

45 Shan K, Bick RJ, Poindexter BJ, Shimoni S, Letsou GV, Reardon MJ, Howell JF, Zoghbi WA, Nagueh SF: Relation of tissue Doppler derived myocardial velocities to myocardial structure and beta-adrenergic receptor density in humans. J Am Coll Cardiol 2000;36:891-896.

46 Liu JE, Robbins DC, Palmieri V, Bella JN, Roman MJ, Fabsitz R, Howard BV, Welty TK, Lee ET, Devereux RB: Association of albuminuria with systolic and diastolic left ventricular dysfunction in type 2 diabetes: the Strong Heart Study. J Am Coll Cardiol 2003;41:2022-2028.

47 Slattery C, Lee A, Zhang Y, Kelly DJ, Thorn P, Nikolic-Paterson DJ, Tesch GH, Poronnik P: In vivo visualization of albumin degradation in the proximal tubule. Kidney Int 2008;74:1480-1486. 